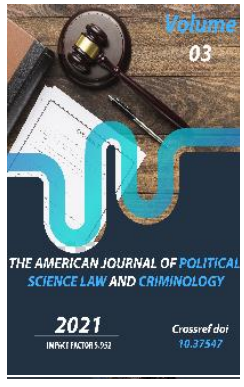

Journal Website: http://usajournalshub.c om/index,php/tajpslc

Copyright: Original content from this work may be used under the terms of the creative commons attributes 4.0 licence.

\section{Legal Analysis Of The Theft And Its Objective Side In Uzbekistan And India: National And Foreign Experience}

F.Kh. Khudaykulov

Lecturer, Department Of Criminal Law, Criminology And Anti-Corruption Of Tashkent State University Law PhD In Law, Uzbekistan

Dr. Divyashree

Asst Professor, School Of Criminology And Behavioural Science Rashtriya Raksha University Lavad, Dahegam, Gandhinagar, Gujarat, India

\title{
ABSTRACT
}

The objective side of theft is characterized by three actions: 1 ) the seizure of someone else's property, or 2) the circulation of someone else's property in favor of the culprit or other persons, or 3) the seizure and circulation of someone else's property in favor of these persons.

\section{KEYWORDS}

Theft, the way (method) of committing a crime, secretly, property, pickpocketing, the objective side of the crime, criminal act, consequence, causal link.

\section{INTRODUCTION}

Given the widespread occurrence of thefts and the significant total amount of damage caused by them, it is advisable to pay special attention to the criminal-legal characteristics of this crime.
The object and the subject of theft do not possess any peculiarities in comparison with the object and the subject of theft in general.

It is possible to make some distinctions between the object of theft and the object of 
related crimes. Theft basically encroaches only on property crimes, in contrast to robbery, robbery, which at the same time can additionally encroach on the life or health of the victim. If we consider the crime of misappropriation or embezzlement, then it additionally affects the interests of the organization in which the offender works, that is, official interests.

Since the object of theft is the property of a citizen, which can be expressed in monetary terms, it is necessary to correctly calculate the amount of damage caused to the victim. In the case of continued theft by theft, when property is stolen from one source in several steps with the intention of the culprit to commit theft on a large scale as a result, the value of all stolen property should be summed up to determine the amount of theft. If one person committed several thefts from different sources, when for each criminal act, the intention of the perpetrator to commit theft on a large scale was formed, the value of all the stolen property should be summed up to determine the amount of theft. When a group of persons commits a theft by prior conspiracy or by an organized group, the amount of the theft is determined by the value of all the stolen property. If the size of the stolen is large, then all participants in the theft are liable for committing the theft on a large scale.

\section{DISCUSSION}

The objective side includes an action (unlawful gratuitous seizure and circulation of someone else's property in favor of the culprit or other persons), the consequence (property damage in the form of loss of property caused to the owner or other owner of this property), a causal relationship between them, as well as a method - theft should be secret.

An obligatory sign of the objective side of theft is the illegality of the seizure and its gratuitousness. Unlawfulness means that the perpetrator is not the owner of the property, did not have a legal right to seize the property and turn it in his favor, was not authorized to do so. In this regard, there is no composition of theft if the person has legal grounds to receive the property seized by him, but violated the procedure for obtaining it. The gratuitousness of the seizure of property is characterized by the fact that the owner does not receive the necessary equivalent in the form of socially useful labor or reimbursement of the value of the object of theft for the property retired from his possession. Partial reimbursement of the value of the seized property does not exclude liability for theft.

The objective side of theft is expressed in actions through which a person secretly steals someone else's property. The peculiarity of theft, which makes it possible to distinguish it from appropriation, waste and other forms of theft, consists in the way it is committed. When theft is committed by theft, the perpetrator is not endowed with any powers in relation to the property; he illegally and gratuitously seizes it against the will of the owner. The seizure of property by a person who does not have the authority to dispose, manage, deliver or store this property should be classified as theft, even if the perpetrator had access to it in connection with the assigned work.

According to the article 169 Criminal Code of Uzbekistan theft, that is larceny in secret - shall be punished with fine up to fifty minimum monthly wages, or correctional labor up to two 
years, or arrest up to six months, or imprisonment up to three years.

Theft committed: a) from the clothes, bag, or other personal belonging, carried by the victim (pickpocketing); b) in large amount; c) by previous concert by a group of individuals; d) with illegal entering a dwelling, depositary or other premise - shall be punished with fine from three hundred minimum monthly wages, or correctional labor from two to three years, or imprisonment from three to five years.

Theft committed: a) repeatedly or by a dangerous recidivist; b) with unauthorized entering a computer system; c) in large amount - shall be punished with imprisonment from five to eight years.

Theft committed: a) in large amount; b) by a special dangerous recidivist; c) by an organized group or in its interests - shall be punished with imprisonment from eight to fifteen years

Thus, theft should be considered secret in the following cases:

1) Property is seized in the absence of the owner, other owner of the property, persons obliged to act in their interests (for example, security guards), and outsiders;

2) Property is seized, although in the presence of these persons, but unnoticed by them (for example, in case of pickpocketing);

3) The property is seized, although in the presence of these persons, but the perpetrator expects that they do not understand the nature of his actions. For example, theft of building materials from the construction site, if the perpetrator expects that the workers present will not pay attention to the loading and removal of these materials or they will consider these actions lawful, theft in the presence of a child who, due to his youth, does not understand that a theft is taking place;

4) The property is seized, although in the presence of these persons, but the perpetrator mistakenly believes that he is acting secretly (he did not notice the persons present or expects that these persons will not notice his actions or do not realize the nature of these actions).

When establishing the secrecy of theft, it is necessary to take into account the nature of the relationship between the offender and the persons present at the commission of the crime.

However, the last provision requires some clarification:

a) Theft remains secret even in the case when not only close relatives, but also other relatives, in-laws, roommates, grooms, brides, accomplices, neighbors, friends, acquaintances, etc. are present during its commission. Only two conditions are necessary for the recognition of the presence of the factor of secrecy: first, due to any life relationship, this person is not an outsider for the guilty person; secondly, the perpetrator expects that, due to these circumstances, the deed will be kept secret;

b) The requirement to stop unlawful actions does not in itself turn theft into robbery. For example, such demands from those close to the perpetrator may be motivated solely by concern for the personal safety of the offender. If at the same time, the criminal expects that the deed will be kept secret; there are no grounds for qualifying the theft as open. 
Under certain circumstances, secret theft (theft) can develop into open theft - robbery or robbery. Therefore, "if in the course of the theft the actions of the perpetrator are discovered by the owner or other owner of the property or other persons, but the perpetrator, knowing this, continues to commit illegal seizure of property or its retention. The deed should be qualified as robbery and in the case of the use of violence that is life-threatening or health, or the threat of using such violence - as robbery»

If, when committing theft, the act is discovered and the perpetrator, leaving someone else's property, simply tries to hide and even uses violence for this purpose. Theft does not develop into robbery and robbery, the deed is qualified as an attempt to steal, and the use of violence - as a crime against the person or against order management (depending on who it is applied to).

If at the time of appropriation the property had already been removed from the possession of the victim (for example, it was lost), the deed cannot be qualified as theft. The current law does not provide for criminal liability for the misappropriation of property found or accidentally found by a person [1, P. 608].

Since theft is a crime with a material composition, the moment of its end must be associated with the onset of consequences in the form of direct damage to the owner or other owner of the property. Theft is recognized as a completed crime not at the moment when the intent to seize someone else's property is fully realized, but when the perpetrator has received a real opportunity to use and dispose of the stolen goods. If the opportunity to dispose of the stolen property did not really exist, the deed must be qualified as an attempted theft [2, P. 10].

The subject of theft can be a sane person who is guilty of a socially dangerous act and is able to bear criminal responsibility for it in accordance with the law. It follows from this that the subject of a crime must have the following characteristics: firstly, sanity and, secondly, reaching the age of criminal responsibility.

According to the article 17 Criminal Code of Uzbekistan, individuals aged fourteen years or above at the moment of commission of a crime shall be subject to liability for the crimes envisaged by Paragraph 1 of Article 97, Articles 98,

104 - 106, 118, 119, 137, 164 - 166 and 169. Paragraphs 2 and 3 of Article 173, Articles 220, 222, 247, 252, 263, 267 and 271, Paragraphs 2 and 3 of Article 277 of this Code.

\section{Basic definition of theft in England.}

1) A person is guilty of theft if he dishonestly appropriates property belonging to another with the intention of permanently depriving the other of it; and "thief" and "steal" shall be construed accordingly.

2) It is immaterial whether the appropriation is made with a view to gain, or is made for the thief's own benefit.

3) The five following sections of this Act shall have effect as regards the interpretation and operation of this section (and, except as otherwise provided by this Act, shall apply only for purposes of this section).

Theft. A person guilty of theft shall on conviction on indictment be liable to imprisonment for a term not exceeding seven years [1]. 
Section 322(1) of the Criminal Code provides the general definition for theft in Canada: 322. (1) Every one commits theft who fraudulently and without colour of right takes, or fraudulently and without colour of right converts to his/her use or to the use of another person, anything, whether animate or inanimate, with intent

(a) To deprive, temporarily or absolutely, the owner of it, or a person who has a special property or interest in it, of the thing or of his property or interest in it;

(b) To pledge it or deposit it as security;

(c) To part with it under a condition with respect to its return that the person who parts with it may be unable to perform; or

(d) To deal with it in such a manner that it cannot be restored in the condition in which it was at the time it was taken or converted [2].

Article 2 of the Theft Ordinance provides the general definition of theft in Hong Kong: (1) A person commits theft if he dishonestly appropriates property belonging to another with the intention of permanently depriving the other of it; and thief and steal shall be construed accordingly. (2) It is immaterial whether the appropriation is made with a view to gain, or is made for the thief's own benefit [3].

Theft is a criminal activity in India with punishments which may lead to jail term. Below are excerpts of laws of INDIAN PENAL CODE which state definitions and punishments for theft.

\section{- $\quad$ Section 378 - Theft.}

Whoever intending to take dishonestly any movable property out of the possession of any person without that person's consent, moves that property in order to such taking is said to commit theft. Explanation 1.-A thing so long as it is attached to the earth, not being movable property, is not the subject of theft; but it becomes capable of being the subject of theft as soon as it is severed from the earth. Explanation 2.-A moving effected by the same act which effects the severance may be a theft. Explanation 3.-A person is said to cause a thing to move by removing an obstacle which prevented it from moving or by separating it from any other thing, as well as by actually moving it. Explanation 4.-A person, who by any means causes an animal to move, is said to move that animal, and to move everything which, in consequence of the motion so caused, is moved by that animal. Explanation 5.- The consent mentioned in the definition may be express or implied, and may be given either by the person in possession, or by any person having for that purpose authority either express or implied [4].

Section 379 - Punishment for theft. Whoever commits theft shall be punished with imprisonment of either description for a term which may extend to three years, or with fine, or with both [5].

Section 380 - Theft in dwelling house, etc.

Whoever commits theft in any building, tent or vessel, which building, tent or vessel is used as a human dwelling, or used for the custody of property, shall be punished with imprisonment of either description for a term which may extend to seven years, and shall also be liable to fine [6].

Section 381 - Theft by clerk or servant of property in possession of master.

Whoever, being a clerk or servant, or being employed in the capacity of a clerk or servant, 
commits theft in respect of any property in the possession of his master or employer, shall be punished with imprisonment of either description for a term which may extend to seven years, and shall also be liable to fine [7].

Section 382 - Theft after preparation made for causing death, hurt or restraint in order to the committing of the theft.

Whoever commits theft, having made preparation for causing death or hurt, or restraint, or fear of death, or of hurt, or of restraint, to any person, in order to the committing of such theft, or in order to the effecting of his escape after the committing of such theft, or in order to the retaining of property taken by such theft. shall be punished with rigorous imprisonment for a term which may extend to ten years, and shall also be liable to fine [8].

Establishing a lowered age of criminal responsibility in relation to persons committing thefts, the legislator, I believe, proceeded, first, from the fact that the social danger of these acts is quite understandable for adolescents and there are minors among those committing crimes against property rights. However, criminal legislation and law enforcement practice strive, first, to reeducate minors, even those who have violated the law. Criminal punishment is applied to them only when a dangerous crime is committed, when it can be concluded from the adolescent's past behavior that he can really be corrected and reeducated only through criminal punishment. In less dangerous cases, educational measures are widely used.

In addition to legal signs, social, moral, ethical and professional characteristics are of great importance in assessing the personality of the culprit, which make it possible to see in the offender not only an abstract "subject of a crime", but also a living person in all the complexity of his mental properties. It is the analysis of these characteristics of the individual as a whole that makes it possible to correctly resolve the issue of individualization of responsibility and punishment, deeply and comprehensively understand the reasons and conditions that gave rise to this crime, and outline the actual preventive measures.

Under the criminological characteristics of a person, it is customary to understand the totality of data on the criminal law, sociodemographic and moral-psychological qualities of a person who has committed a crime.

The application of criminal law measures to persons who have committed a crime involves not only establishing the characteristics of the subject of a crime, but also taking into account certain personality traits. These data are widely used in constructing qualified corpus delicti and in sentencing.

The subjective side of theft involves a direct intent to seize someone else's property. The direction of intent in theft is determined by selfish motives and goals.

Today, the full protection of the rights and freedoms of citizens is everyone is one of the most important tasks of the state [9].

Every country measures to ensure the security and inviolability of its borders have the right to see [10.]

As for the selfish motive, its essence consists in the desire of the guilty to satisfy his material needs at someone else's expense by seizing property to which he has no right. A selfish goal takes place both in cases of turning someone 
else's property in favor of the guilty person, and in cases of transferring it to other persons, in whose financial situation the guilty party is interested.

It goes without saying that such cases are a crime is a sign that further increases the level of social risk [11].

The requirement of a selfish goal does not apply to accomplices who may act due to other motives (family or friendship ties, under the influence of threats or violence, or due to service dependence). It is only important that these persons know the nature of the act committed by the performer.

The subjective side of theft involves the establishment of two mandatory features: 1) intentional guilt in the form of direct intent; 2) a selfish goal.

Direct intent when committing theft lies in the fact that the perpetrator realizes. The public danger of his secret actions for the unlawful and gratuitous seizure and conversion of another's property in his favor or the benefit of other persons. foresees the possibility or inevitability of consequences in the form of direct damage to the owner or other owner of the stolen property and wants them to come.

The importance of the objective aspect of the crime can be expressed in the following: social danger, which indicates how the committed crime was committed, is the appearance of the act [12].

A selfish goal, that is, the desire of the perpetrator to obtain material benefits by illegal means. It is expressed in the desire to have the actual opportunity to illegally own, use and dispose of someone else's property as his own, that is, personally consume or use it in another way, sell, donate, lend to other persons, as payment for debt or services rendered. Secret illegal seizure and circulation of someone else's property in one's own favor or for the benefit of other persons, carried out without a selfish purpose, cannot be qualified as theft, but can entail criminal liability for the destruction or damage of someone else's property, arbitrariness, theft of vehicles.

\section{CONCLUSION}

The conducted research on the topic "Criminal and legal characteristics of theft" allows us to draw the following conclusions:

1. Theft is one of the most widespread and frequent forms of theft.

2. According to the law, theft is a secret theft of someone else's property. Secrecy should be understood as: seizure of property in the absence of its owner and other persons. They are: seizure of property in the presence of the owner, but unnoticed by him; seizure of property in the presence of the owner or other persons, when the perpetrator incorrectly believes that he is acting in secret; seizure in the presence of persons, when the perpetrator expects that they do not understand the nature of his actions. The secrecy of the crime should be decided based on a subjective criterion, which is, based on the assessment of the situation by the perpetrator himself.

3. By design, the composition of theft is material, since the objective side of the crime has a mandatory feature - the onset of socially dangerous 
consequences as material harm. Theft is considered completed from the moment the offender gets a real opportunity to dispose of the property of others seized by him at his own discretion, regardless of whether he was able to realize it.

4. The subjective side of theft is characterized by the presence of guilt in the form of direct intent and selfish motive.

Penetration is illegal if a culprit who has no right to do so carries it out. Intrusion should be understood as secret or open intrusion into a room or other storehouse with the aim of committing theft of someone else's property. In any case, penetration must be carried out with the purpose of theft. In this case, it is necessary that this target was before penetration. If a person was in a room or other storage facility lawfully, without criminal intent, but then committed theft, it cannot be qualified as committed with penetration.

Premises "mean buildings and structures, regardless of the form of ownership, intended for the temporary location of people or the placement of material assets for production or other official purposes."

In addition, the storage facility is recognized as "utility rooms, isolated from residential buildings, areas of the territory, main pipelines, and other structures, regardless of the form of ownership, which are equipped with a fence or technical means or provided with other security and are intended for permanent or temporary storage of material values."

\section{REFERENCES}

1. https://www.legislation.gov.uk/ukpga/ 1968/60

2. Criminal Code, RSC 1985, c c-45, s 322 (https://laws-

lois.justice.gc.ca/eng/acts/C-46/page-

154.html\#h-95).

3. "Cap. 210 THEFT ORDINANCE". legislation.gov.hk.

4. "Definition of theft - Section 378 in India penal code". India code - a repository of state and central acts. Ministry of law and justice. Retrieved 23 March 2020.

5. $\quad$ Punishment for theft - Section 379 in India penal code". India code - a repository of state and central acts. Ministry of law and justice. Retrieved 23 March 2020.

6. "Theft in dwelling,house etc - Section 380 in India penal code". India code - a repository of state and central acts. Ministry of law and justice. Retrieved 23 March 2020.

7. https: // indiacode.nic.in / showdata?actid=AC_CEN_5_23_00037_1860 45_1523266765688\&orderno $=438$

8. "Theft after preparation made for causing death, hurt or restraint in order to the committing of the theft - Section 382 in India penal code". India code - a repository of state and central acts. Ministry of law and justice. Retrieved 23 March 2020.

9. Алланова А. НЕЗАКОННЫЙ ВЫЕЗД ЗА ГРАНИЦУ ИЛИ ВЪЕЗД В РЕСПУБЛИКУ УЗБЕКИСТАН. ПОНЯТИЕ И ОСОБЕННОСТИ //Review of law sciences. - 2018. - №. 2.

10. АЛЛАНОВА А. қонунга хилоф равишда чет элга чиқиш ёки 
Doi: https://doi.org/10.37547/tajpslc/Volume03Issue04-13

ўзбекистон республикасига кириш

учун жиноий жавовгарлик: муаммо ва таклиф //юрист ахборотномаси. 2021. - T. 2. - №. 1. - C. 166-174.

11. Allanova A. Aggravating circumstances of illegal travel abroad or illegal entry into the Republic of Uzbekistan //Review of law sciences. - 2020. - T. 4. - №. 1. - C. 3 .

12. Алланова А. Антисоциальное поведение несовершеннолетнегообъективный признак преступления в виде вовлечения в действия //Review of law sciences. - 2020. - T. 2. - №. Спецвыпуск.

13. Khudaykulov F. K. Signs Of The Objective Side Of Crime In The Theory Of Criminal Law Belonging To The Romano-Germanic Legal Family: Theoretical And Practical Problems //The American Journal of Political Science Law and Criminology. - 2021. T. 3. - №. 01. - C. 57-62. 